\title{
Artium
}

Architecture, Urbanism, Design and Construction

Vol. 9, Issue 2, August 2021

Journal homepage: http://artium.hku.edu.tr

DOI: $10.51664 /$ artium. 881947

\section{Tasarım Sürecinde Çevresel Algının Sınırlarını Diyalektik Bakış Açısıyla Yeniden Belirlemek}

\author{
Güliz Muğan ${ }^{1}$ \\ Prof. Dr., İstanbul Okan Üniversitesi, Sanat, Tasarım ve Mimarlık Fakültesi, İstanbul, TÜRKIYE \\ ORCID ID: 0000-0003-3676-0872
}

ÖZ

Bireyin fiziksel çevreyi yapılandırma üzerindeki etkisi ve fiziksel çevrenin de bireyin davranışları üzerindeki belirleyici rolü çevresel algıyla başlar. Çevresel algı sürecinin, öznel yapısına ve zaman zaman farkındalığımızdan uzak durumuna rağmen, tasarımcılar için geliştirilmesi ve detaylandırılması gerekmektedir. $\mathrm{Bu}$ da ancak açıklayıcı bir araştırma yaklaşımını benimseyerek güvenilir bilginin ortaya çıkartılmasıyla mümkün olacaktır. Bu noktada, diyalektik yaklaşım, herhangi bir mekânsal tasarımı oluşturmak için gerekli seçenekleri ortaya koymada ve onların ilişkide olduğu temel bireysel, toplumsal, kültürel sistemi anlamada tasarım olgusunun kavramsal özelliklerini etkileyen eleştirel bir yöntem olarak sunulabilir. Bu bağlamda, bu makalenin temel amacı, tasarım sürecindeki aktörlerin çevresel algıyla ilişkili bilgi edinimlerini bir çevreyi 'tanımlayarak' başlayan ve çevreye 'değer biçme'yle devam eden sistematik bir çerçeve etrafında diyalektik yaklaşıma dayandırmanın önemini vurgulamaktır. Bu maksatla, değer biçme ölçütlerinin diyalektiği, farklı çevresel tasarımlar üzerinden örneklendirilmiş, böylece çevresel alg1 sürecinin diyalektik yöntemin dört tür ilişkisiyle açıklandığında ve örneklendirildiğinde, çevresel değişimin kaçınılmaz olduğu açıklanmaya çalışılmıştır. Bu sayede, tasarımcıların bu yaklaşım sayesinde edinmeleri beklenilen detaylı bilginin, tasarım sürecine katkı sağlayacağı, süreci pekiştireceği ve hayatın değişim ve etkileşimlerini yakalayabilen, toplumsal ilişiklere ve kültürel farklılıklara duyarlı alternatif tasarım seçenekleri oluşturması sürecine ilişkin bir yol haritası oluşturulmuştur.
MAKALE BİLGIISI

Geliș: 02 / 03 / 2021

Kabul: 27 / 07 / 2021

ANAHTAR KELIMELER

Çevresel algı,

Diyalektik yöntem,

Kişisel izlenim

Değer biçme

\section{Determining the Boundaries of Environmental Perception through Dialectical Perspective in the Process of Design}

\begin{abstract}
The influence of individuals in constructing the physical environment as well as the significant role of the physical environment on the behaviours of the individuals start with the environmental perception. Despite the fact that environmental perception is a subjective issue and it mainly works at the level of unawareness, its processing should be improved and elaborated for the designers. This can only be possible by adopting an explanatory research approach in order to reveal the reliable knowledge. At this point, dialectical approach can be presented as a critical method which affects the conceptual features of the design phenomenon by putting forward the necessary alternatives for the spatial design as well as by understanding the individual, social and cultural systems that are related to different design alternatives. In this respect, the major aim of the article is to emphasize the significance of basing the knowledge about environmental perception that the actors in the design process should acquire to the dialectical approach through a systematic framework which starts with the description and continues with appraising. With this purpose, the dialectics of the environmental appraisal was exemplified though different environmental designs. Hence, it was tired to be explained that environmental change and progress were inevitable when the process of environmental perception was explained though the four relationships of the dialectical method. This effort of discussion can be considered as building a road map for the designers during the design process where the detailed information which will reinforce the process and can catch the dynamics and interactions of life. Thus, alternative design processes, which are more sensitive to social relationships and cultural differences, can be constructed.
\end{abstract}

ARTICLE HISTORY

Received 02 / $03 / 2021$ Accepted 27 / $07 / 2021$

KEYWORDS

Environmental perception

Dialectical approach

Individual impressions

Environmental appraisal

\section{GíRIŞ}

Birey ve bireyin içinde bulunduğu sosyo-fiziksel çevre arasındaki etkileşimi çalışan bilim dalı olarak tanımlanan çevre psikolojisi alanı, bireyin fiziksel çevresinden -ister yapıl1, ister doğal- ayrı düşünülemeyeceği prensibi üzerine kuruludur (Gifford, 2002; Göregenli, 2013). Bireyin 
fiziksel çevreyi dönüştürüp, değiştirmesi ve fiziksel çevrenin de bireyin davranışları üzerindeki belirleyici rolü, fiziksel olduğu kadar sosyal bir olgu olan çevre-insan arasındaki sürekli ve organik ilişkinin kaçınılmaz sonucudur (Kuban, 2014). Bu ilişkinin başlangıç noktası kuşkusuz çevresel algıdır. Çevresel algının, herhangi bir nesneyi algılamaktan farkı, sadece çevresel algıda bulunan uyarıcının büyüklüğü ve karmaşıklığından öte, temelde algılayanın rolüyle ilgilidir. Başka bir deyişle çevresel algıda birey bir sahne içerisinde hareket eder; mizansenin bir parçası haline gelir.

Hayward (2012) mizanseni tanımlarken hem 'sahneye koyma' anlamındaki tiyatro terimine değinir, hem de sinemada çekimlerin çerçevelenmesine ilişkin, ortam, kostüm, aydınlatma ve çerçeve içindeki hareketi içeren film yapım uygulamalarından bahseder. Bu tanımdan yola çıkarsak, içinde bulunduğu çevreyi algılamaya başlayan birey de aynı sahneye koyulan bir oyundaki veya çekilen bir filmdeki oyuncu gibi o sahnedeki rolü gereği sergilediği davranışları, hatta giydiği kostümleriyle çevrenin/mizansenin ayrılamaz bir parçası haline gelir. Çevreyi algılama sürecinde o mizanseni yaratır ve mizansen tarafından da rolü/kimliği inşa edilmiş olur. Proshansky, Fabian ve Kaminoff (1983), kişinin mekânla olan ilişskisinin ve deneyimlerinin kimliğin inşa sürecindeki kaçınılmaz rolünün altını çizerken, aynı zamanda fiziksel çevrenin ancak içindeki sosyal yapı, kişilerarası ilişkiler ve kültürel öğelerle bir anlam kazandığının da önemini vurgularlar.

Bu noktada bir örnek verecek olursak, sınıf dediğimiz mekânın belirleyici birtakım yapısal özelliklerini (sıra, tahta, kürsü, kapasitesi vb.), sosyal çevresine dair özelliklerden (öğrenciler, öğretmenler ve bu iki grup arasında süregelen ders, sınav vb. ilişkiler) ayrı düşünmemiz imkânsızdır. Başka bir deyişle, öğretmen ve öğrencilerin varlığı, orada bir ders işleniyor olması, sınıfı "sınıf" şeklinde adlandırmamızdaki en temel belirleyicilerden biridir. Aynı zamanda, sıraların düzeni, sıra ve tahtanın ilişkisi, hoca kürsüsünün yeri, mekânın büyüklüğü gibi fiziksel özellikler de o mekânı kullanan hoca ve öğrencilerin davranışlarını, (nerede durmalılar, nereye bakmalılar, nasıl giyinmeliler, nasıl konuşmalılar vb.) dolayısıyla da başka mekânlarda sergiledikleri başka kimlik özelliklerinden farklı olarak belirler. Ve tüm bu süreç temelinde bir öğrenci veya öğretmenin bir mizansenin parçası olması, belirli rolleri belirli dekorlar içerisinde canlandırmasıyla; yani sınıf denilen çevreyi algılamasıyla ilgilidir. Bu bağlamda, çevreyi değiştirme, dönüştürme, yaratma ve aynı şekilde çevrenin bireyin davranışlarını oluşturması, etkilemesi ve hatta kimlik inşa sürecine olan etkisi, temelinde çevresel algıyla başlar.

Vitruvius'un (2015) Mimarlık Üzerine On Kitap'ta (The Ten Books on Architecture) belirttiği üzere kuramsal bilgiden yoksun olarak uygulama gerçekleştirmeye çalışan mimarın yetkinliğinden bahsetmek mümkün değildir. $\mathrm{Bu}$ da bizi, çevresel alg1 sürecinin, öznel yapısına, zaman zaman farkındalığımızdan uzak durumuna ve çevreye uyumlanmadaki bilgi kayıplarımıza rağmen, geliştirilebilir olduğu sonucuna yaklaştırır; en azından tasarımcılar için geliştirilmesi ve detaylandırılması kaçınılmaz olmak durumundadır. Bu da ancak açıklayıcı bir araştırma yaklaşımını benimseyerek güvenilir bilginin ortaya çıkartılmasıyla mümkün olacaktır. Bu noktada, diyalektik yaklaşım, herhangi bir mekânsal tasarımı oluşturmak için gerekli seçenekleri ortaya koymada ve onların ilişkide olduğu temel bireysel, toplumsal, kültürel sistemi anlamada tasarım olgusunun kavramsal özelliklerini etkileyen eleştirel bir yöntem olarak sunulabilir.

Diyalektik yöntem, bir çeşit dünyaya bakmanın farklı bir biçimi olarak önemli bir açıklama modeli olarak sunulabilir. İlk olarak Hegel tarafından geliştirilen, sonrasında 'Marx'ın diyalektik yöntemi' olarak bilinen yaklaşım, dünyayı incelemeyi, çıkarımları düzenlemeyi ve bu çıkarımları insanlara sunmayı içeren bir yöntemdir (Ollman, 2011). Ollman’a (2011, s. 34) göre “bütünden parçaya, sistemden içeriye ilerleyen bir yaklaşım olarak diyalektik araştırma öncelikle dört tür ilişkinin izini sürer ve açığa çıkmasını sağlar: özdeşlik/farklılık, zıtların iç içe geçmişliği, nitelik/nicelik ve çelişki." Marx'ın diyalektik anlayışında bu ilişskiler, bir şeyin nasıl işlediğini ve bunun ortaya çıkmasını sağlayan sistemi anlamak için kullanılır. $\mathrm{Bu}$ dört ilişkiyi kısaca özetlemek gerekirse, Marx'a göre şeylerin içinde bulunduğu ilişkiler ağında hem özdeş hem de farklı gözüken ilişkilere aynı anda sahip olabilirler. Karşıtlıkların iç içe geçmişliğinde herhangi bir şeye (olay, kurum, kişi, süreç) başka bir noktadan, kişi tarafindan veya başka koşullar altında bakıldığında karşımıza taban tabana zıt sonuçlar çıkabileceğini kavramamız beklenir. Nitelik/nicelik ilişkisinde, her süreç niceliksel bir değişimle başlayıp niteliksel bir değişime evrilir. Niteliksel değişim niceliğin bir neden-sonuç ilişkisinin neticesinden ziyade yeni bir kavramı ifade etmek için kullanılır. Herhangi bir gerçeklikten diyalektik bir anlam çıkarma çabası içerinde bu dört ilişki içerisinden en önemlisi çelișkidir (Ollman, 2011). Çelişki aynı ilișki içerindeki birbirine bağlı farklı öğelerin birbirine karşıt gelişimi sürecini ifade eder. Bir değişim sürecini belirleyen şey kendi içindeki çelişiklerdir; sorunlardır. Nicelik/nitelik ilişkisinde olduğu gibi çelişkili şeyler arasında da nedensellikten bahsetmek hatalı olacaktır. Gelişen her sistemin ve süreç olan şeylerin içerinde çelişki vardır. Çelişkilerin izini sürmek, olası problemlerin nedenlerini keşfetmeye ve çözümleme sürecine yardımcı olacaktır. Marx bu dört ilişki üzerinden bütünden parçaya ilerlerken parçaların bağımlılık ilişkisini vurgulayarak kapitalist toplumun işleyişini yeniden inşa eder (Ollman, 2011). Peki bu noktada, diyalektik düşünceye sahip bir tasarımcı, çevresel alg1 sürecini bu yöntem dahilinde anlamlandırarak ve geliştirerek, çevre tasarımını bütünden parçaya analiz ederek, var olan bireysel ve toplumsal ilișkileri vurgulayarak alternatif tasarım seçenekleri oluşturabilir mi? 'Çevre yaratan' rolüyle (Kuban, 2014), çevrenin bireyin kimlik inşa sürecine olan etkisini belirleyebilir mi?

$\mathrm{Bu}$ bağlamda, bu makalenin temel amacı, tasarım sürecindeki aktörlerin çevresel algıyla ilişkili bilgi edinimlerini sistematik bir çerçeve etrafında diyalektik yaklaşıma dayandırmanın önemini vurgulamaktır. Ayrıca, bir diğer amaç, çevresel alg1 sürecinin, diyalektik yöntemin dört tür ilişkisiyle açıklandığında ve örneklendirildiğinde, çevresel değişimin kaçınılmaz olduğunu ortaya koymaktır. 


\section{ÇEVRESEL KAVRAYIŞIN PEKISSTTIRILILMESINDE KİSISEL İZLENIMLERI KULLANMA}

Kenneth Craik (1968) The Comprehension of the Everyday Physical Environment ${ }^{1}$ başl1klı makalesinde, insanların içerisinde hareket ettikleri gündelik fiziksel dünyanın biliş düzeyinde daha iyi nasıl kavranabileceğini, bununla ilgili ne çeşit sınıflandırmalar yapılması gerektiğini, hangi beklentilerin ve hangi özelliklerin bireyin herhangi bir fiziksel çevreyi kavrayışında belirleyici olduğunu yöntemsel strateji düzeyinde tartışmaya açmış, çevre psikologlarının bu bağlamda tasarımcılar ve planlamacılarla kaçınılmaz ortaklığının altını çizmiştir. Craik'e (1968) göre, davranış bilimleri alanında yapılan araştırmaların toplumsal önemine ve izlenilen yöntem ve elde edilen bulguların uygulamaya ilişkin katkılarına dönük farkındalık arttıkça, tasarım disiplinleriyle olan yakınlık da gün geçtikçe gelişecektir ki nitekim öyle olmuştur. Çevre psikolojisinin yeni yeni psikoloji alanından ayrışmaya başladığı dönemlerde, Craik'in tasarımcıların fiziksel çevreyi daha iyi kavramalarına dönük bu yöntemsel çerçeve çabası, Gifford (2002) tarafından altı çeşit kişisel izlenimin de eklemlenmesiyle yeniden uyarlanmıştır: tanımlama, değer biçme, estetik değerlendirme, duygular, anlam ve güvenlik. $\mathrm{Bu}$ izlenimler tamamen öznel çıkarımlara açık olmakla birlikte, mesleki deneyimlerin ortak çıkarımlarıyla bir araya geldiklerinde tasarım alanına yöntemsel olarak kuşkusuz daha fazla katkı sağlayacaktır. Bu makalede yapılmaya çalışılansa, çevre algısını geliştirme sürecinde bir çevreyi 'tanımlayarak' başlayan ve çevreye 'değer biçme'yle devam eden analiz sürecini diyalektik yöntem çerçevesinde yorumlamaya dair örneklemeler sunmak ve tasarımda diyalektik bakış açısının önemini vurgulamak olacaktır.

Ollman (2011), içinde yaşadığımız dünyayı kavramaya dönük üç şeyden bahseder: dünyanın nasıl bir yer olduğunu tanımlamak, bizim kim olduğumuzun etkisi ve dünyadaki olguların dinamik yapısını incelemede kullandığımız yöntem. Bu noktada, Ollman'ın dünyayı kavramaya dönük bu üç ilkesini tasarımcının çevresel analiz sürecini açıklamak ve örneklendirmek için kullanabiliriz: daha nesnel olan tanımlama izlenimi, bunu takiben bizim kim olduğumuzla daha çok ilişkilendirebileceğimiz tanımladığımız çevresel özelliklere değer biçme izlenimi ve onları açıklamak için kullanılan diyalektik yöntem analizi. Böyle bir analiz özünde diyalektik yöntemin temel ilişkilerini de içermektedir.

\section{ÇEVREYI TANIMLAMAK}

Çevre algısı ve analizi özünde içinde bulunduğumuz çevreleri tanımlayarak başlar. Tanımlamak, çevrenin fiziksel ve sosyal yapısına yakından bakmak demektir.

\footnotetext{
${ }^{1}$ Makalenin Türkçesi için "Gündelik Fiziksel Çevrenin Kavranışı” şeklinde çeviri gerçekleştirilebilir.

${ }^{2}$ Beş duyumuzu kullanarak algıladığımız dünyaya dair özellikler hem zaman hem de mekân bağlamında bir şeyin nerede bitip diğer şeyin nerede başladığına dair kavramsal sınırlar ve ayrımlar zihinsel ve toplumsal bir inşa sürecinin sonucudur. İşte, dünyayı kavramsallaştırırken, bu sınırların nasıl çizileceği üzerine düşünmeye 'soyutlama' denir. Marx'a (1904) göre beș
}

Gifford'ın (2002) da söylediği gibi temel olarak 'orada ne var?' sorusunun yanıtını bulmaya çalışırken, serbest çağrışımsal bir yöntem izlenmektedir. Bir çeşit detaylı bir listeleme olduğu söylenebilir. Analizin derinleşmesi, tanımlamayla başlayacağından bu noktada herhangi bir niteleme yapmaktan kaçınıp, daha nesnel ve detaylı bir liste yapma gayreti o çevreye daha yakından bakmamızı da sağlayacaktır. Burada yapılmak istenen, çevresel gerçekliğin aslında ilk bakışta algılanan şeyden çok daha fazlası olduğunu açıklamadan önce, gözümüze çarpan anlık parçaların bir bağlam içerisinde sıralanmasıdır diyebiliriz. Fiziksel ve sosyal özellikleri bir bütünün birbirinden bağımsız parçaları olmaksızın, aynı çevrenin etkileşimsel zeminindeki iki yapının farklı özellikleri olarak sıralanması diyalektik açıdan önemlidir. Fiziksel yapıya ilişkin, rakamsal büyüklükler, ölçüler, yükseklikler, yap1 elemanları, kullanılan nesnelerin sayıları, malzemeleri gibi noktaları, sosyal yapının, kişi sayıs1, yapılan iş, süren etkileşimsel ilişkiler gibi özellikleriyle nesnel bir şekilde, bir değer yargısı belirtmeksizin ve mümkün olduğunca niceliksel olarak fazla detaylı bir şekilde sunumu tasarımcıların bir çevreyi tanımlarken kullanabilecekleri ipuçları olarak verilebilir (Canter, 1969; Gifford, 2002). Tabi bu noktada, diyalektik bakış açısıyla çevreyi bütün olarak tanımlarken nicelik ve nitelik arasındaki değişim ilişkisini unutmamak gerekir. Niceliksel olarak tanımlanan çevre, nitelendiği andan itibaren başka bir algı sürecinde başka bir değişimle mercek altına alınacaktır. Burada amaç, sürekli değişim ve etkileşim içerisinde olan çevreleri gözümüzün önüne sermektir.

Çevre içerindeki öğelerin tanımlanması, onları nasıl düzene sokacağımıza karar verme ve o çevreyle ilgili çıkarımda bulunma, yani diyalektik analizin başlangıç noktasıdır. Bu başlangıç noktasıyla kapsamlı bir çevre analizi, bir çevreyi küçük parçalar ve o parçaların birbiriyle olan ilişkisine bakmak suretiyle yeniden inşa etmektense, diyalektik bir yaklaşımla, o çevreyi karşılıklı bağımlı süreçler olarak soyutlayıp ${ }^{2}$, bütünün tam bir resmini, ondan ne anlaşıllyorsa onu ortaya sermeyi hedefler. Değer biçme süreciyse, tanımlanan bütünsel çevrenin nasıl işlediğini ve işlemesi gerektiğini anlatan çözümsel sürecin devamlılığı niteliğindedir. Çünkü sonunda başlangıç noktası olan tanımlamaya geri dönülüp bütün çevreye dair net bir kavrayış tamamlanmış olacaktır. Bir çevreyi somutlamak, içinde gerçekleşen süreçlerin izini sürmek ve sonrasında o çevrenin neye dönüşeceğine, ne şekilde tasarlanacağına karar vermek çevreyi tanımlayarak başlar; bu çevre ister okuldaki bir sınıf ölçeğinde, ister kent ölçeğinde olsun.

\section{ÇEVREYE DEĞER BİÇMEK}

Bir çevreyi fiziksel ve sosyal yapısına dair tüm parçalarının biraradalığının uyumu bağlamında bütünsel

duyumuzla algıladığımız haliyle dünyanın bize kendini olduğu gibi sunması 'gerçek somut' tur. Ancak bütünü incelemek için kullanacağımız ussal parçalara ayırma süreci olan 'soyutlama' sürecine geçtiğimiz zaman gerçek somutun karmaşıklığından sıyrilıp, düşüncede yeniden oluşturulan ve kavranan somuta ulaşabiliriz. Gerçek somutun karmaşıklığı soyutlama süreciyle düşünsel somuta, yani aydınlığa ulaşır ki bu da dünyayı yeniden inşa etme sürecidir (aktaran, Ollman, 2011). 
olarak tanımladıktan sonra, o çevreyi daha derinlemesine kavramak, var olan özellikleri eleştirip, daha insani çevreler yaratmak adına, tasarımcının öznel kimliğinin belirleyici olduğu ikinci adım gereklidir: çevreye değer biçmek. Gifford (2002) bir çevre analizi için gerekli olduğunu düşündüğü altı izlenimden bir tanesi olarak değer biçme ${ }^{3}$ izleniminden bahseder. Herhangi bir ölçekteki çevreye dair fiziksel ve sosyal yapının tanımlamasını, detaylı ve nesnel bir listeleme olarak kabul edersek, değer biçmenin listenin her bir maddesini öznel süzgecimizden geçirme ve sıfatlar aracılığıyla niteleme süreci olduğunu söyleyebiliriz. Başka bir deyişle, algılanan çevre hakkında değer yargısında bulunmaya başlarız.

Bir değer yargısı oluştururken şüphesiz en genel yargımız, Gifford'ın (2002) da bu izlenime ilişkin belirlediği "iyi mi?" sorusuna verilecek iki cevaptan bir tanesi olacaktır: iyi veya kötü. Ancak, özellikle çevreyi şekillendirme rolünü üstelenenlerin bir çevrenin fiziksel ve sosyal yapısına dair özelliklere değer biçerken içerikten bağımsız 'iyi/kötü' şeklindeki yorumlarının, bir temele dayandırılmaksızın, nedenselleştirilmeden bırakıldığında herhangi bir çevrenin kavramsallaştırılması, dönüştürülmesi veya oluşturulması için son derece yetersiz kalacağının altını çizmek gerekir. Bu nedenle, bir çevreye ilişkin yargımızı oluştururken kavramsal ölçütlerimizi belirlemek ilk adım olmalıdır. Bu çerçevede, Gifford'ın bahsettiği izlenimlerden olan, çevrenin içerdiği önem, estetik yargısı, duygulanmaya dair yargılar ve güvenlik yargıları da kapsayıcılıkları bağlamında kullanılabilecek değer biçme ölçütleri olarak sunulabilir.

\section{DEĞER BİÇME ÖLÇÜTLERINDE DIYYALEKTIK YAKLAŞIM}

Bir çevreye herhangi bir değer yargısında bulunurken parasal değer, kalite, mekânsal organizasyon gibi diğer kavramsal ölçütlerin yanı sıra, 1sı, 1şık gibi fiziksel yapıya dair başka ölçütlerden de bahsetmek mümkündür. Bu noktada Gifford'ın (2002, s. 70) sunduğu tasarlanmış çevrelerin anlamını ölçmek için kullandığı anlamsal ölçekten örnek verebiliriz. Bir çevrenin kullanıcılar için içerdiği önemi sorgulamak çevresel algı çalışmalarının çoğunlukla öncelikli kaygısı olmakla birlikte, çevre tanımlamalarında, değer biçmede veya duygulanımlarda da başat izlenim ölçütü olarak ilk akla gelendir. Bir çevrenin bizim için ne kadar işlevsel olduğu, mekânlarla kurduğumuz aidiyet veya bir mekânın bizim için ideolojik önemi değer yargılarımızda kuşkusuz belirleyici olmaktadır. Örneğin, bir restoranın kalitesine değer biçerken mekânsal diyalektiklere dair düzen ve 1sı gibi kavramları, sosyal diyalektiklere dair de restoranın fiyatlarını ölçüt almışsak, restoranın içerdiği öneme dair de alg1 sürecimizi ortaya koymuş oluruz. Düzen için, temizpis; 1sı için 1lık-serin ve fiyatlar için de pahalı-ucuz sıfat ikililerinden bir tanesini seçtiğimiz zaman restoranın işlevselliği veya sosyal sınıf anlamında kapsayıcılığ $/$ dışlayıcılığg1, o restoranın çevresel deneyimini karşıtlıklarla veya niceliksel değişimin (örn. fiyat çeşitliliğinin), niteliksel değişime (örn. sosyal sınıf tanımlaması) evrilmesi yoluyla açıklamış olur. Bu yargılarımızı, nedenleriyle ortaya koyduğumuzdaysa sürecin takipçileri ve eylem planlayıcıları için, artık o çevreye biçilen değerin bir anlamı, karşılığg ve işlevi ortaya çıkmış olur ki, bu da yeni tasarlanacak çevreler için referans olarak faydalı bilgi niteliğindedir.

Değişkenler çeşitlendikçe, kullanacağımız ölçeklerimiz, yani diyalektiklerimiz de kuşkusuz artacaktır. Bu diyalektiklerin her zaman zıtlıklar içermesi de gerekli değildir. Örneğin, bir mekânın plan yapısı üzerindeki karedikdörtgen plan ikiliği, kullanıcıların beğeni ölçütü üzerinde çevresel algıyı ve deneyimi açıklamak için kullanılmıştır (Nasar, 1981). Çevresel tercihlerde biliş konusunda en bilindik ve önemli çalışmaları yürütmüş olan Stephen ve Rachel Kaplan'a (1978) göre ise, bir çevrenin bizim belirli hedeflerimize ulaşmamıza yardımcı olan işlevsel özellikleri çevrelere dair değer yargılarımızda belirleyici ölçüttür. Buna göre bir çevrenin kolay kavranabilir olması ve kullanıcıda o çevreye dahil olma fikri yaratması çevreye ilişkin işlevsel bir değer yargısı oluşturması açısından önemlidir. Başka bir deyişle, temel işlev bir çevrede kaybolmadan ve aynı zamanda sıkılmadan vakit geçirebilmektir. $\mathrm{Bu}$ değişkenleri ölçülebilir kılmak için Kaplan'lar tutarl1-karmaşık ve anlaşılabilir-gizemli gibi mekânsal diyalektikleri tartışmaya almışlardır.

Herhangi bir yapının vurgulamaya çalıştığı veya tasarımcısının niyetinin tersine vurgulayamadığı soyut kavramsal iletişim de çevreye değer biçme sürecinde sorgulanması gereken anlama dair önemli ölçütlerdendir. Mekânların kullanıcı ve tasarımcıyla girmiş olduğu ideolojik iletişim süreçlerini doğru değerlendirmek tasarımcıya o mekânların içerdiği öneme dair değer yargısı oluşturma şansı tanıyacaktır. Böyle bir diyalektik bakış açısı, yapıların ve mekânların sadece belirli bir zamana ve yere bağlı koşullar altında değerlendirilmemesi gerektiğini, zıtlıkların biraradalığının değişime olan etkisini de ortaya koymaktadır. Burada, Charles Jencks'in (2011a) reformist mimari hareketine dahil edilebilecek olan radikal post-modernizm anlayışından bahsedebiliriz. Yirmi birinci yüzyılın mimari yapılarının kent kültürünü, çevre koşullarını ve kullanıcı beklentilerini ve yaşam biçimlerini temel tasarım unsurlarıyla bir arada sunan yapıs1, Jencks'in mimarlıktaki radikal post-modernizm tanımının temelini oluşturmaktadır. Mekânsal diyalektik çerçevesinde baktığımızda, bir taraftan sıra dışıyken diğer taraftan tanıdıklık hissi veren bu mimari yapılar, aynı zamanda kullanıcıların geleneksel anlayışını içerirken, tasarımcının çağdaş tasarım çizgisini de barındırmaktadır. İletişimin ön plana çıktığı, karmaşayı ve çoğulculuğu gündemine alan, kullanıcının isteklerinin ağır bastığg ve evrensel sembolizmin kodlarından oluşan bu yeni mimari, kullanıcılar tarafindan beğenilmek ve tercih edilmekle birlikte esasen tüketim toplumunun gereğini oluşturmaktadır. Madrid'deki Forum La Caixa ${ }^{4}$ binası

\footnotetext{
${ }^{3}$ Gifford'ın (2002, s. 69) “Evaluations: Is it good?” başlığında anlattığ izlenimin çevirisi makale bağlamında değer biçme olarak tartışılmıştır.
} 
(bkz. Resim 1) böyle bir ideolojik okumaya ve değerlendirmeye örnek gösterilebilir (Jencks, 2011b).

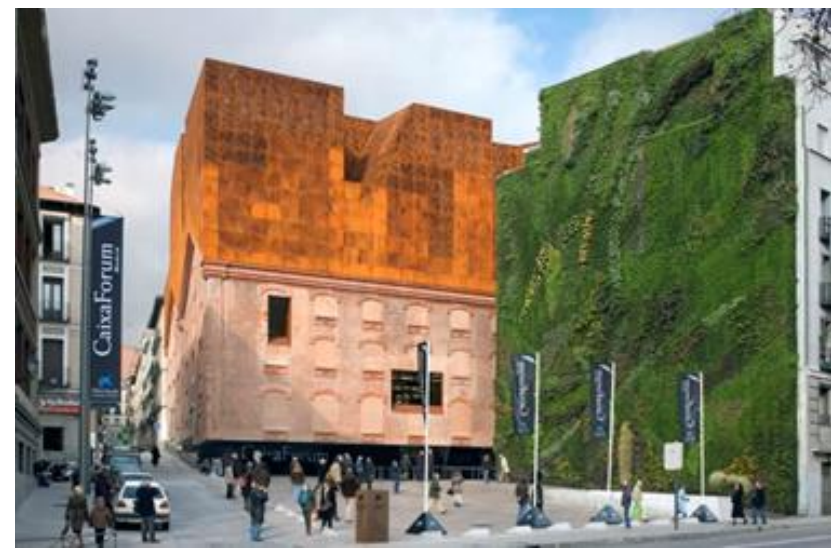

Resim 1. Forum La Caixa, fotoğraf: Duccio Malagamba (Madrid, 2008)

Tasarlanmış çevreye ilişkin en çok başvurulan değer biçme ölçütlerinden bir diğeri de güzellik yargısıdır. Güzelliğin bakılan şeyin özünden mi, yoksa bakanın gözlerinin o şeyi öyle görmesinden mi kaynaklandığına ilişkin tartışma doğal çevre ve yapılı çevre bağlamında farklı şekillenebilir. Bakılan şey, doğal çevreye dair birtakım özellikler veya doğal çevrenin kendisi olduğunda, birçoğumuzun yemyeşil ormanları, el değmemiş sahilleri, hatta 1ssız bucaksız çöl manzaralarını 'güzel yargısı' çerçevesinde değerlendirmemiz çok daha kolay olacaktır. Oysa, söz konusu olan tasarlanmış bir çevre yani herhangi bir ölçekteki yapılı çevre olması durumunda, tasarımcıların ve kullanıcıların farklı ölçütlere ihtiyacı olacaktır. Hatta, doğal çevrenin de güzellik yargısının herkes için ortak kabul görmeyeceği söylenebilir. Bu konuyla ilgili yapılan ilk ve önemli araştırmalardan bir tanesi Texas'taki çam ve meşe ağacı ormanlarının doğal güzelliğini karşılaştırmış ve en fazla görsel nüfus ediniminin $^{5}$, manzara güzellik yargısına dair en iyi güzellik yargısı ölçütü olduğunu belirtmiştir (Ruddell, Gramann, Rudis ve Westphal, 1989). Ortak özellikleri bağlamında özdeş gözüken bu iki ormanın farklılığını ortaya koymak güzellik için değer biçerken diyalektik ilişkinin yöntemsel olarak kullanımını içermektedir. Bu bağlamda, yapılı herhangi bir çevre düşünüldüğünde güzellik yargısını belirleyecek ölçütlerin çeşitliliği çok daha fazladır. Malzeme kullanım çeşitliliği, renk ve doku kullanımı, plan yapısı vb. düşünüldüğünde, güzellik yargısını tasarımcı için çeşitlendirebilecek çok farklı parametreler ortaya çıkmaktadır ve bu parametreler güzellik yargısını sadece birey için değil, toplum için de belirlemeye devam etmektedir. $\mathrm{Bu}$ çerçevede güzellik yargısı üzerine düşünürken, tasarımcının herhangi bir çevrenin birbirine bağlı farklı öğelerinin karşıt kullanımı ve gelişiminin, çelişkilerden ve zıtlıklardan kaynaklı yeni bir güzellik yargısı inşa ettiğinin farkındalığı, çevrenin farklı şekillerde algılamasında önemlidir. Günümüz tasarımlarında karşımıza sık sık birlikte çıkan doğal malzeme/endüstriyel malzeme kullanımı, zit renklerin aynı mekân içerisinde kullanımı, asimetrik planlar, iç mekânların diş mekân ve doğal çevreyle iç içe geçmişliği, bu yeni güzellik anlayışının örnekleri olarak sunulabilir. Tasarımcı, bireysel ve toplumsal olarak değişen güzellik yargısının içindeki çelişkileri ve zıtlıkları aramaya başladığında tasarım sürecinin çelişkilerini ve sorunlarını da keşfetmeye başlar ki diyalektik düşüncenin özünde olan da budur.

Bir çevrenin bize kendimizi nasıl hissettirdiği de güzellik yargısıyla doğrudan ilişkilidir. Güzel bulduğumuz bir çevrede kendimizi memnun hissederiz ve davranışsal olarak orada daha fazla zaman geçirmek, o çevrenin daha çok parçası olma eğiliminde bulunuruz. Mehrabian ve Russell'ın (1974) çevre psikolojisi alanında duygularla ilgili öncü çalışmasını ${ }^{6}$ hatırlarsak kendimizi mutlu ve heyecanlı hissettiğimiz mekânlara daha çok yaklaşmayı istiyoruz. Mutlu hissettiğimiz mekânlarda orta düzeyde duygusal uyarılmanın, yani heyecanın eksik olması durumu, o mekânın sıkıcı olarak tanımlanma ihtimalini ve dolayısıyla mekândan kaçınılmasına sebep olabiliyor. Başka bir deyişle duygusal zıtlıkların hissedilmesine dönük düzenlemelerin belirli ölçüde bir arada yapıldığı mekânların davranışsal olarak tercih edildiğini söyleyebiliriz. Düzen/karmaşa veya içerde/dişarda diyalektiğinin orta düzeyde yansitılabileceği her tür mekânsal düzenleme kullanıcılar için sadece memnuniyet değil, aynı zamanda duyusal uyarılmaya da sebep olmakta, bu da karşıtlıkların dinamizminin ortaya çıkardığı yeni sonuçların, yani değişimin potansiyelini içermektedir. Bu noktada, son yıllarda değişen alışveriş merkezi (AVM) tasarımlarını örnek verebiliriz. Son yollarda sayıları hızla artan, açı alanların içlerine taşındığ 1 , sokak düzenlemelerinin ve deneyimlerinin eklemlendiği yeni nesil AVM'ler artık bina formlarıyla sınırlı değil. Artan rekabetin, insanların, geleneksel alışveriş anlayışını, AVM'lerin sosyalleşme, hijyen, güvenlik vb. özellikleriyle bir arada bulma tercihi (Erkip, 2019) diyalektik boyutların tasarım sürecindeki değişen seçeneklerde kaçınılmaz olduğunu net bir şekilde ortaya koyuyor.

memnuniyet içerirken, duygusal uyarılma, bir ucunda uyku hali ve durgunluk diğer ucunda ise coşkulu heyecan içeren dairesel bir dizi olarak ifade edilir. Yaklaşma ve kaçınma davranışı da memnuniyet ve uyarılma arasındaki etkileşimle ilgilidir: Memnuniyet verici bir çevrede, yüksek düzeyde duygusal uyarılma o çevreye daha fazla dâhil olma isteği doğururken (örn: eğlence parkları), memnuniyetsiz hissettiğimiz bir çevrede, yüksek düzeyde duygusal uyarılma o çevreden kaçınma veya uzaklaşma davranışını ortaya çıkaracaktır (örn: mahkeme salonlari). 
Çevre analizi yaparken güvenlik/risk değeri de aynı ölçüde diyalektik bakış açısıyla ele alınması gereken önemli bir ölçüt olarak karşımıza çıkar. Bir çevrede kendimizi güvende veya tehlikede hissetmemizin, o çevredeki duygusal uyarılmamız üzerinde de etkisi kaçınılmazdır. Hemen hemen her gün yaşadığımız, çalıştığımız veya ziyaret ettiğimiz mekânların içerdikleri tehlike unsurunu değerlendiririz ve bununla ilgili mekânsal, toplumsal ve sosyal ölçütler ortaya koymaya çalışırız. Güvenliğe ilişkin izlenimler çoğunlukla suç, kazalar, çevresel kirlilik ve tehlikeler gibi unsurlara bağlı olarak ortaya çıkar (Gifford, 2002). Oturduğumuz mahallenin toplumsal yapıs1, karşılaştığımız insanların görünüşleri, sosyal sınıf özellikleri, kentsel uygarlık anlayışının dışında kalan davranışlar, (Muğan, 2018) yaşanılan yerdeki aydınlatılmamış noktalar, (Loewen, Steel ve Suedfeld, 1993) boş alanların yeşillendirilmesi, (Shaffer ve Anderson, 1985) hatta çocukların sokakta tek başlarına oynayıp oynayamayacağı, karşıya geçip geçemeyecekleri (Ampofo-Boateng, 1989) gibi değişkenler hem mekânsal hem de sosyal diyalektikler üzerinden güvenlik yargısını ölçülebilir hale getirmektedir. Özellikle sosyal ve toplumsal karşıtlıklar ve çelişkiler bağlamında sıkça tartışılan güvenlik kavramı, sokaklara, meydanlara, AVM'lere yerleştirilen güvenlik kameraları ve sürekli kameraları faal olan akıllı cep telefonları gibi teknolojik gelişmelerle de diyalektiği üzerine düşünülmesi gereken bir hale gelmiştir. Sürekli gözetlenerek denetim altında olma hali kamusal alanın güvenliği/bireysel özgürlükler veya kamusal/mahrem diyalektiklerini tartışmaya açar. Bu diyalektiklerin mekânsal kullanıma ve mekânsal tercihlere yansıması, kamusal alanın dönüşümünü de etkilemesi bağlamında ayrıca önem içermektedir (Batuman, 2010). Erkip (2019) bu durumu şu şekilde açıklar: Trafik yoğunluğu, fiziksel altyapı eksiklikleri, geceleri yeterli aydınlatılmayan sokaklar, artan suç oranları, yaşlıların, engellilerin, özellikle de son yıllarda kadınların ve çocukların sokaklar yerine AVM'ler gibi daha denetimli mekanları tercih etmesinde belirleyici olurken, kentin sokak yaşantısından da ciddi bir kopma gözlemleniyor. Bu da kentsel mekânların politik ve ideolojik dönüşümüne, kamusal alanın şekil değiştirmesine sebep olmaktadır. Fakat bu noktada, karşıtlıkların iç içe geçmişliği bağlamında düşündüğümüzde, şekil değiştiren yeni kamusal alanlarda alınan güvenlik önlemlerinin ayrımcılığ 1 normalleştiren bir hale getirmesi de bu değişim sürecinin kendi içerisindeki çelişkilerini ortaya koymaktadır (Mugan-Akinci, 2015). Başka bir deyişle diyalektik bakış açısıyla bu süreci değerlendirdiğimizde, niceliksel olarak sayıları artan güvenlik kameraları ve güvenlik görevlilerinin yarattığı değişim niteliksel bir farka dönüşmektedir: Güvenlik önlemlerinin artmas1, kamusal alanlardaki ayrıştırıcı ve dışlayıcı rollerinin normalleşmesine evrilirken, kimin gözetlenen, kimin gözetleyen olduğunun rastlantısallı̆̆ 1 , mahremiyetin ihlaline ve kimi zaman tekinsiz bir çevre algısına neden olmaktadır (Erkip, 2019). Bu çerçevede, günümüz kentlerindeki çevre algısındaki değişimi güvenlik/risk çelişkisi üzerinden analiz etmek, yeni tasarlanacak çevreler için farklı güvenlik anlayışları geliştirmeyi de gerekli kılabilir demek yanlış olmayacaktır.

\section{DEĞERLENDIIRME ve SONUÇ}

Çevre algısının çoğu zaman farkındalığımızdan uzak ve otomatik işleyen durumu fiziksel çevrenin başa çıkabileceğimizden çok daha fazla parçalı bilgi sunumuyla birleştiğinde, genellikle çevre algısının belirli amaçlara yönelik şekillendiğini söyleyebiliriz. Bu bağlamda da iki temel amaçtan söz edilebilir: Faydacı ve estetik amaçlar (Gifford, 2002). Başka bir deyişle gündelik hayatımızda çevreler içerisinde gezinirken daha çok işimize yarayan ve/veya estetik olarak beğendiğimiz mekânlara yönelik bilgiyi algılayıp, saklamayı tercih ettiğimizi söyleyebiliriz.

Kuşkusuz, Kuban’ın (2014) belirttiği üzere, günümüzde 'çevre yaratan' olarak bakılan mimarlar, iç mimarlar, kentsel planlamacılar vb. meslek gruplarının çevreyi algılama biçimleri ve algı detaylarının yetkinliği, her ölçekteki yapısal çevrenin sadece işlevsel ve estetik olarak birkaç kişinin farkındalığında olmasındansa, daha büyük bir bütünün organik bir parçası olması ve sürekli ilişikler ağına hizmet etmesi açısından önem taşımaktadır. Başka bir deyişle, çevre alg1 süreci tasarım aktörleri için gelişmeye, ilerlemeye ve etkileşimlerin çözülmesine dönük evrilmeye ihtiyaç duyar. Böylece, tasarım alanının bu aktörleri, insanın çevreyi, çevrenin de insanı yaratmasına katkı sağlayabilir. Bu da ancak, çevresel alg1 sürecinin bu meslek grupları için bilimsel olarak ortaya konması ve daha insani çevreler yaratmak adına çevreye dair algılanan bilginin geliştirilip, belirli bir sistematik çerçevesinde detaylandırılmasına dönük yöntem ve tavırlarla mümkün olacaktır.Bu bağlamda, diyalektik bakış açısı sadece ekonomik ve sosyal yapıyı açıklamak, kapitalizmde neler olup bittiğini ve onun nereye doğru ne şekilde ilerlediğini açıklamak için değil, özellikle 70'li y1llardan sonra insan etkinliğini, toplumsal ilişkileri, kişilerarası ilişkileri ve psikolojik süreçleri açıklamada, anlamlandırmada ve çözümleme sürecinde kullanılan işlevsel bir yöntem haline gelmiş olması sebebiyle tasarım sürecinde önemli bir rol oynar (Göregenli, 2013).

Bu makalede, Gifford'ın (2002) çevresel analize dair sunduğu altı çeşit izlenim 'tanımlama' ve 'değer biçme' başlıkları altında toplanarak, çevrenin içerdiği önem, estetik, duygulanımlar ve güvenlik ölçütleri, yöntemsel olarak diyalektiğin izini sürdüğü dört temel ilişki bağlamında örneklenmeye ve tasarımcıların herhangi bir çevreyi değerlendirme süreçlerinde izleyebilecekleri bakış açısı olarak ortaya konmaya çalışılmıştır. Böylece, kaçınılmaz olan çevresel değişimin arkasındaki tasarım sürecinin çelişkilerinin ve sorunlarının kavranmasına dönük yaklaşımın önemi vurgulanmak istenmiştir. Tasarımcıların bu yaklaşım sayesinde edinmeleri beklenilen detaylı bilginin, tasarım sürecine katkı sağlayacağ 1 , süreci pekiştireceği ve hayatın değişim ve etkileşimlerini yakalayabilen, toplumsal ilişiklere ve kültürel farklılıklara duyarlı alternatif tasarım seçenekleri oluşturması sürecine ilişkin bir yol haritası oluşturulmuştur.

\section{KAYNAKÇA}

Ampofo-Boateng, K. (1989). “Children's Perception of Safety and Danger on the Road", Dissertation Abstracts International, 49 (10-B), s. 4567-4568. 
Batuman, B. (2010). Röntgenle(n)me: Kamusal Alanda Görsel Takip ve Direniş, Arredamento Mimarlık, 9, 80-83.

Canter, D. (1969). An Intergroup Comparison of Connotative Dimensions in Architecture, Environment and Behavior, 1, $37-48$.

Craik, K. H. (1968). The Comprehension of the Everyday Physical Environments, Journal of the American Institute of Planners, 34, 29-37.

Erkip, F. (2019). Piyasa Yapmanın Yeni Yüzleri: AVM'ler, Sokaklar, Kentler, İstanbul, İletişim Yayınları.

Gifford, R. (2002). Environmental Psychology: Principles and Practice, Canada, Optimal Books.

Göregenli, M. (2013). Çevre Psikolojisi: Insan-Mekan İlişkileri, İstanbul, İstanbul Bilgi Üniversitesi Yayınları.

Hayward, S. (2012). Sinemanın Temel Kavramları, Çeviren U. Kutay, M. Çavuş, İstanbul, Es Yayınları.

Jencks, C. (2011 a). What is Radical Postmodernism, Architectural Design, 81 (5), s. 14-23.

Jencks, C. (2011 b). Contextual Counterpoint, Architectural Design, 81 (5), 62-67.

Kaplan, S. \& Kaplan, R. (1982). Cognition and Environment: Functioning in an Uncertain World, New York, Praeger.

Kuban D. (2014). Mimarlik Kavramlarl: Tarihsel Perspektif içinde Mimarlı̆̆ın Kuramsal Sözlüğüne Giriş, İstanbul, YEM Yayınları.

Loewen, L. J., Steel, G. D., \& Suedfeld, P. (1993). Perceived Safety from Crime in the Urban Environment. Journal of Environmental Psychology, 13, 323-331.

Marx, K. (1904). A Contribution to the Critique of Political Economy, Çev. N.I. Stone, Chicago, Charles H. Kerr.

Mehrabian, A. ve Russell, J. A. (1974). An Approach to Environmental Psychology, Cambridge, Mass: M.I.T. Press.

Muğan-Akınc1, G. (2015). The Purposes and Meanings of Surveillance. Security Journal, 28 (1), 39-53.

Muğan, G. (2018). The Role of Space and Time Use Behaviors in Shaping the Incivility Experience of Young People, Megaron, 13 (2), 182-191.

Ollman, B. (2011). Diyalektiğin Dansı: Marx'ın Yönteminde Adımlar, İstanbul, Yordam Kitap.

Nasar, J.L. (1981). "Responses to Different Spatial Configurations", Human Factors, 23, s. 439-446.

Proshansky, H. M., Fabian, A. K., \& Kaminoff, R. (1983). Placeidentity: Physical World Socialization of the Self, Journal of Environmental Psychology, 3(1), 57-83.

Ruddell, E. J., Gramann, J. H., Rudis, V. A. \& Westphal, J. M. (1989). The Psychological Utility of Visual Penetration in Near-view Forest Scenic-Beauty Models, Environment and Behavior, 21, 393-412.

Shaffer, G. S. \& Anderson, L.M. (1985). Perceptions of the Security and Attractiveness of Urban Parking Lots, Journal of Environmental Psychology, 5, 311-323.

Vitruvius, M. (2015). Mimarlık Üzerine On Kitap [The Ten Books on Architecture], Çeviren S. Güven, Ankara, Şevki Vanlı Mimarlık Vakfi Yayınları. 